\title{
Fluoride content of UK retail tea: comparisons between tea bags and infusions
}

\author{
C. H. S. Ruxton ${ }^{1}$ and T. J. Bond ${ }^{2}$ \\ ${ }^{1}$ Freelance Dietitian, Nutrition Communications, 26 East Road, Cupar, KY15 4HQ and ${ }^{2}$ Technical expert, \\ Tea Advisory Panel, 52a Cromwell Road, London SW7 5BE
}

Tea provides around $70 \%$ of adult fluoride $\left(\mathrm{F}^{-}\right)$intakes in the UK, with mean intakes estimated as $540 \mathrm{ml}$ daily for all adults, and 662 $\mathrm{ml}$ for older adults ${ }^{(1)}$. A recent analysis ${ }^{(2)}$ concluded that the $\mathrm{F}$ - content of some economy tea bags was too high, risking $\mathrm{F}$ - intakes which may exceed safe limits, assuming a daily tea intake of $1 \mathrm{~L}$. However, the infusions were made up using $2 \mathrm{~g}$ of tea in $100 \mathrm{ml}$, whereas a typical serving of tea is generally $3.125 \mathrm{~g}$ of tea in $240 \mathrm{ml}^{(3)}$. This, plus the long brewing time of $2-30 \mathrm{minutes}$ may have overestimated F-content. Therefore, the present study set out to investigate the F-content of UK tea bags using a more typical infusion method and based on average tea intakes.

Retail samples of tea bags, i.e. 28 black, 10 decaffeinated and 11 speciality (white, green, single estate black), were obtained from UK-based tea manufacturers and retailers. For total F-, three tea bags were selected at random from each lot and, after combining, were ashed at $600^{\circ} \mathrm{C}$. The ash was cooled, acid digested and the solution cooled to approximately $20^{\circ} \mathrm{C}$. A total ionic strength adjustment buffer was added to correct the $\mathrm{pH}$ and the sample was measured for $\mathrm{F}$ - using an ion selective electrode. For infused $\mathrm{F}$-, three tea bags were added separately to individual beakers after which $240 \mathrm{ml}$ of freshly boiled de-ionized water was added. 40 seconds later, the tea bags were squeezed gently against the sides of the beakers and removed. The three individual brews were combined, stirred and cooled to approximately $20^{\circ} \mathrm{C}$ before aliquots were taken and F-content measured as for total F-. The entire process was carried out in triplicate. The results are shown below.

\begin{tabular}{|c|c|c|c|c|}
\hline & & Blended black & Decaffeinated black & Speciality \\
\hline Total $\mathrm{F}^{-}(\mathrm{mg} / \mathrm{kg})$ & $\begin{array}{l}\text { Mean } \\
\text { Range }\end{array}$ & $\begin{array}{l}1082 \\
(540-1700)\end{array}$ & $\begin{array}{l}1200 \\
(750-1800)\end{array}$ & $\begin{array}{l}769 \\
(25-1300)\end{array}$ \\
\hline Total $\mathrm{F}^{-}$(mg/bag) & $\begin{array}{l}\text { Mean } \\
\text { Range }\end{array}$ & $\begin{array}{l}3.38 \\
(1 \cdot 68-5 \cdot 31)\end{array}$ & $\begin{array}{l}3.75 \\
(2 \cdot 34-5.62)\end{array}$ & $\begin{array}{l}2.40 \\
(0.07-4.06)\end{array}$ \\
\hline Infused $\mathrm{F}^{-}(\mathrm{mg} / \mathrm{L})$ & $\begin{array}{l}\text { Mean } \\
\text { Range }\end{array}$ & $\begin{array}{l}4.91 \\
(2 \cdot 14-9 \cdot 33)\end{array}$ & $\begin{array}{l}6 \cdot 64 \\
(2 \cdot 91-8 \cdot 25)\end{array}$ & $\begin{array}{l}3.06 \\
(1.0-3.06)\end{array}$ \\
\hline Infused $\mathrm{F}^{-} /$serving $(240 \mathrm{ml})$ & $\begin{array}{l}\text { Mean } \\
\text { Range }\end{array}$ & $\begin{array}{l}1 \cdot 18 \\
(0 \cdot 51-2 \cdot 23)\end{array}$ & $\begin{array}{l}1.59 \\
(0.69-1.98)\end{array}$ & $\begin{array}{l}0.73 \\
(0.24-0.73)\end{array}$ \\
\hline $\begin{array}{l}\text { EDFI } 540 \mathrm{ml} \\
\text { EDFI } 662 \mathrm{ml}\end{array}$ & & $\begin{array}{l}2.65 \\
3.25\end{array}$ & $\begin{array}{l}3 \cdot 59 \\
4.40\end{array}$ & $\begin{array}{l}1.65 \\
2.03\end{array}$ \\
\hline EDFI $662 \mathrm{ml}+$ fluoridated water & & 3.91 & 5.06 & 2.69 \\
\hline
\end{tabular}

Key: EDFI, estimated daily F- intake assuming mean $(540 \mathrm{ml})$ and upper $(662 \mathrm{ml})$ daily tea consumption

Compared with the previous analysis ${ }^{(2)}$, our study found higher F- levels per $\mathrm{kg}$ but similar F- levels per L, despite the different brewing method. However, estimates of $\mathrm{F}$ - intake, based on $540 \mathrm{ml}$ or $662 \mathrm{ml}$ tea per d, were lower and remained below the EU Upper Limit of $7 \mathrm{mg}$ per day ${ }^{(4)}$ even assuming use of fluoridated water in the brew. This suggests that typical tea drinking in the UK does not pose a risk for health and, indeed, may provide benefits for dental health given EU approved health claims for fluoride ${ }^{(5)}$

This work was funded by the Tea Advisory Panel, which is supported by an unrestricted educational grant from the UK Tea \& Infusions Association.

1. Henderson L, Gregory J \& Swan G (2002) National Diet and Nutrition Survey. TSO: London.

2. Chan L, Mehra A, Saikat S et al. (2013) Food Res Int 51, 564-70.

3. Ruxton CHS \& Hart VA (2011) Br J Nutr 106, 588-95.

4. European Food Safety Authority (2006) EFSA Journal 192,1-65.

5. European Food Safety Authority (2009) EFSA Journal 7,1212. 